Research Journal of Applied Sciences 5 (3): 204-211, 2010

ISSN: $1815-932 \mathrm{X}$

(C) Medwell Journals, 2010

\title{
Anthropogenic Activities-Implications for Ground Water Resource in Okrika, Rivers State, Nigeria
}

\author{
I. Tamunobereton-Ari, E.D. Uko and V.B. Omubo-Pepple \\ Department of Physics, Rivers State University of Science and Technology, \\ 500001, Port Harcourt, Nigeria
}

\begin{abstract}
This study reports the locating of possible and suitable sites to drill boreholes for safe, portable and sustainable water supply to the ever-growing population and industries in the area and the vulnerability of this water body to pollutant as a result of human and industrial activities in the area. Data collected from vertical electrical sounding were used to interpret laterally and vertically varying succession of high and low resistive geoelectric layers throughout the area of study. Chemical analysis of three Pollutants Lead $(\mathrm{Pb})$, Copper $(\mathrm{Cu})$ and Nickel $(\mathrm{Ni})$ was carried out on 60 soil samples collected randomly from 10 locations at various depths from the ground surface to $25 \mathrm{~m}$ depth to determine their total concentration in the soil at ground surface and their degree of leaching towards the groundwater of the area. Energy Dispersive X-Ray Fluorescence (EDXRF) technique was used to analyze and determine the total concentration of the pollutants in the soil samples. The results show that there is good aquifer distribution laterally across the study area with aquifer thickness of between $50-60 \mathrm{~m}$ and the groundwater resource of the area is less vulnerable to pollutants because of the presence of a thin layer of organic matters and clay deposits that adsorb the pollutants of interest and minimize the leaching of the pollutants towards the saturated zone.
\end{abstract}

Key words: Resistivity, aquifer, leaching, groundwater vulnerability, pollutants, porosity

\section{INTRODUCTION}

Groundwater is an important natural resource that supplies billions of gallons of water for drinking, agriculture, industrial purposes and other uses. The known surface water bodies in the area are severely polluted by direct discharge of domestic and industrial waste into them as such about $95 \%$ of the population of the area now solely depends on groundwater as their source of water. Thus, harnessing and preservation of clean and safe groundwater becomes imperative.

The study area (Okrika) is a host to the Port Harcourt Refining Company (PHRC) a subsidiary of the Nigerian National Petroleum Corporation (NNPC), jetty and terminal for loading and unloading of oil and gas and other oil and gas servicing activities; these had led to the continuous influx of associate companies and people into the area whose activities had contaminated and polluted available surface water resources by the discharge of effluents or pollutants in runoff into the surface water. Consequently there was an increase demand for portable and sustainable water supply in the area which necessitated the conduct of these hydrogeological and geophysical studies of the area to provide useful information to the location of productive aquifers and possible drilling of such formations to meet the water needs of the evergrowing population and the industries of the area. Vertical electric sounding (i.e., Schlumberger sounding) method was used to obtain the data due to the simplicity of the technique, easy interpretation and rugged nature of the associated instrumentation, it is also economical, quick and effectively used in both soft and hard rock areas which has been proven in solving most groundwater survey problems in different parts of the world (Breusse, 1963; Zohdy and Jackson, 1969; Frohlich, 1974; Urish and Frohlich, 1990).

This method has also been used successfully to determine saltwater-freshwater interface and the lateral extent of saltwater intrusion in the Niger Delta (Zohdy, 1969; Etu-Efeotor et al., 1989; Amadi and Amadi, 1990; Oteri, 1990).

Water has some physical characteristics that guaranteed its wholesomeness: it must be colourless, odourless, tasteless and readily foam with soap or detergents. The human body and blood is composed of $60-75 \%$ of water as such needed enough water at least 2-3 $\mathrm{L}$ for adult to enhance the effective functioning of the circulatory and metabolic systems of the body. Safe water must be used for domestic and agriculture purposes; anything contrary is harzardous to man and his

Corresponding Author: V.B. Omubo-Pepple, Department of Physics, Rivers State University of Science and Technology, 500001, Port Harcourt, Nigeria 
environment. Safe water is dependent on the chemical components of the water. To ascertain the safe status of the groundwater; soil samples were obtained across the study area at various depths for analysis to evaluate the degree of leaching of surface pollutants towards the groundwater resource (Aloway and Ayres, 1997). Therefore, the provision of baseline hydrogeological, geophysical and safety information of aquifer characteristics of the area became inevitable based on the high demand for quality, safe and sustainable water supply to meet the water need of humans and industries in the area and to ensure public health.

Local geology of the study area: Okrika in Rivers State, Nigeria located in the coastal area of the Niger Delta as shown in Fig. 1 is characterized by its beaches, mangroves, swamps and barrier bars. The area lies between longitude $7^{\circ} 00^{1}$ East and $7^{\circ} 50^{1}$ West and latitude $4^{\circ} 45^{1}$ South of Rivers State (Nigeria, Federal surveys, $2,500 / 364 / 6-68)$. The area is underlain by the coastal plain sands (Benin formation) which is predominantly sandy (>90\%) with a few intercalation of shale beds. The sands and the sandstones are coarse grained and are mostly coloured because of limonite coating, presence of hematite grains and feldspar minerals. The shales are grayish-brown, sandy or silty and contain some plant remains and dispersed lignite (Short and Stauble, 1967). These formations are commonly masked by thick partly weathered layers of the recent Niger Delta sediments and dense vegetation which ranges from secondary to freshwater swamp flora in the inland and mangrove swamps at the coast. The high porous and unconsolidated sands of the Benin formation have been identified as the freshwater bearing sands (Short and
Stauble, 1967; Mbonu et al., 1991). The area is within the mangrove freshwater swamps hydrogeological Province underlain primarily by the deltaic plains formation. Aquifers are encountered at varying depths and points with variations of water qualities. The depth of the water table ranges from few metres to tens of metres as you move from the Okrika Island inland to Okrika mainland based on the topography of the area. The high permeability, the over lying lateritic earth materials containing dense vegetation, the weathered top of the formations as well as the underlying shale strata provide the hydrologic conditions that favoured aquifers in the area (Todd, 1959; Plummer and McGeary, 1993).

The considerable thickness of the aquifers, the high transmissivity of these aquifers due to the high degree of porosity and permeability and the adequate groundwater recharge capacity enhanced by the high annual rainfall in the area makes the aquifers of the area reliable water resources that can yield and supply reasonable millions of $\mathrm{m}^{3}$ volume of water to satisfy the water needs of the people and industries of the area through both public and private abstractions. Also, the aquifers in this area are less vulnerable to pollution despite the continuous human and industrial activities in the area which perhaps is due to the presence of Organic and clayey deposits at the top layer of this area that may have provided mechanical filtration of colloidal pollutants such as pathogens and chemicals owing to their fine-grain sizes and sorption of charge pollutant species due to their charged surfaces and large surface areas; this favours the washing away of pollutant deposited on the surface by runoff thereby minimize or prevent the leaching of pollutant down to the groundwater during percolation of rain water or snow that

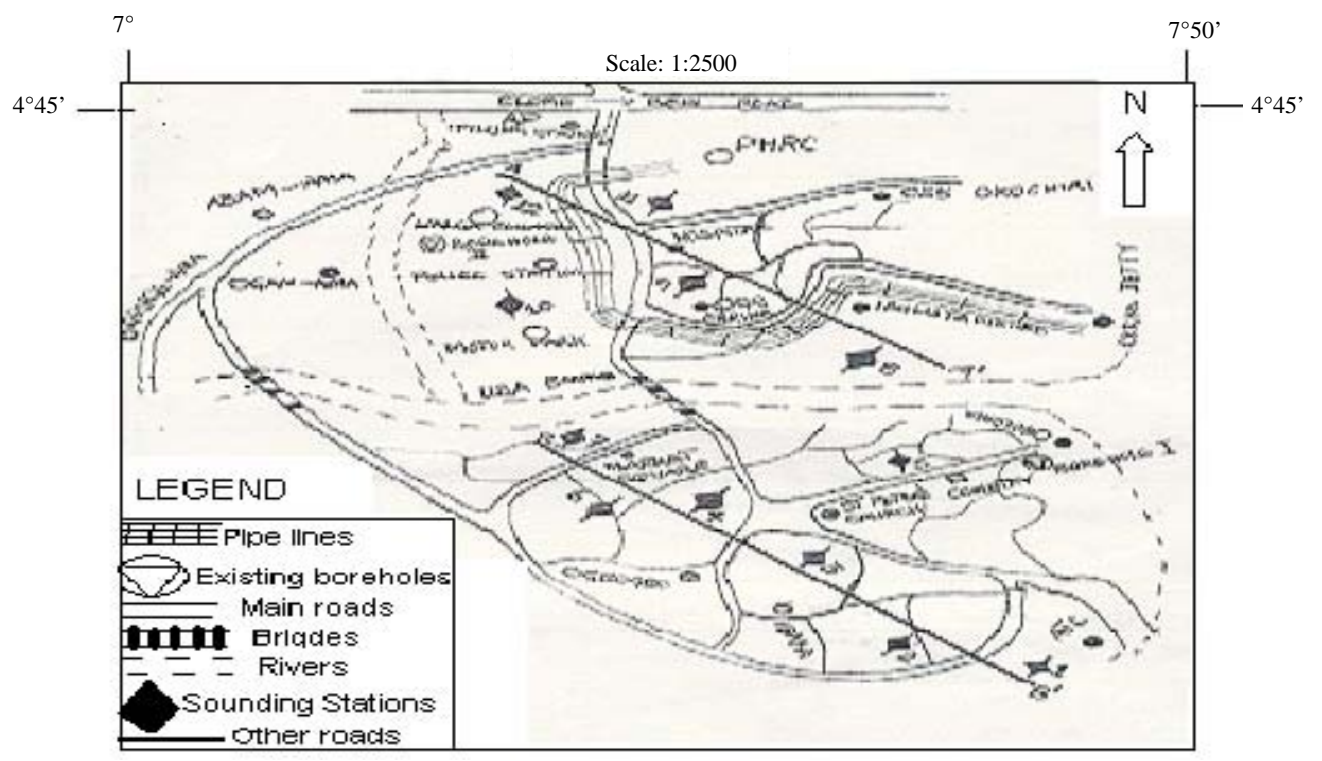

Fig. 1: Map of the study area showing the sounding locations 
precipitate on ground surface. In this area, the development of borehole is easy because of the considerable unconsolidation of the formation materials and the shallowness of the saturated zone (Todd, 1959; Plummer and McGeary, 1993; Aloway and Ayres, 1997; Kilner et al., 2005).

\section{MATERIALS AND METHODS}

To obtain the hydrogeologic data of the study area, Vertical Electric Sounding (VES) method was used and the soundings were carried out at 12 different stations shown in (Fig. 1) along two profiles using the Schlumberger electrode configuration with a maximum current electrode separation of $600 \mathrm{~m}$. A digital self-averaging Resistivity meter. The R-Plus was used for data acquisition by displaying the apparent Resistivity of the different layers. Quantitative interpretation of the field curves was done by the conventional curve matching technique using the three layer master curves and drawing auxiliary point diagrams (Koefoed and Dirks, 1979). Computer assisted interpretation was used to obtain the desired results of the resistivities and thicknesses of the geoelectric layers as shown in Table 1 and Fig. 2 and 3 show the graphical presentation of the results.
The implications of the anthropogenic activities on the groundwater resource of the study area was determined by the chemical analysis of 60 soil samples collected randomly from 10 locations at various depths from ground surface to about $25 \mathrm{~m}$ deep at $5 \mathrm{~m}$ interval identified by A-to-F: $A=0 \mathrm{~m}, \mathrm{~B}=5 \mathrm{~m}, \mathrm{C}=10 \mathrm{~m}, \mathrm{D}=15 \mathrm{~m}$, $\mathrm{E}=20 \mathrm{~m}$ and $\mathrm{F}=25 \mathrm{~m}$. This depth range was chosen because the water table in the area of study is shallow and falls between 20-30 m deep and this sampling design was used to evaluate the degree of leaching of pollutants at the surface down the earth's interior during percolation of rain or snow waters. The samples collected were oven dried and grinded to the desired particle size of about nanometers $10^{-9} \mathrm{~m}$ for analyses. For the determination of the total concentrations of the pollutants, the soil samples were analyzed with a multi-elemental analytical tool; the Energy Dispersive X-Ray Fluorescence (EDXRF) SPECTRA X-LAB 2000 Model shown in Fig. 2 (Kebbekus and Mitra, 1997; Stead-Dexter and Ward, 2004; Aloway and Ayres, 1997).

\section{RESULTS AND DISCUSSION}

The numerical data of the geoelectric sounding survey are shown in Table 1. Showing the resistivity

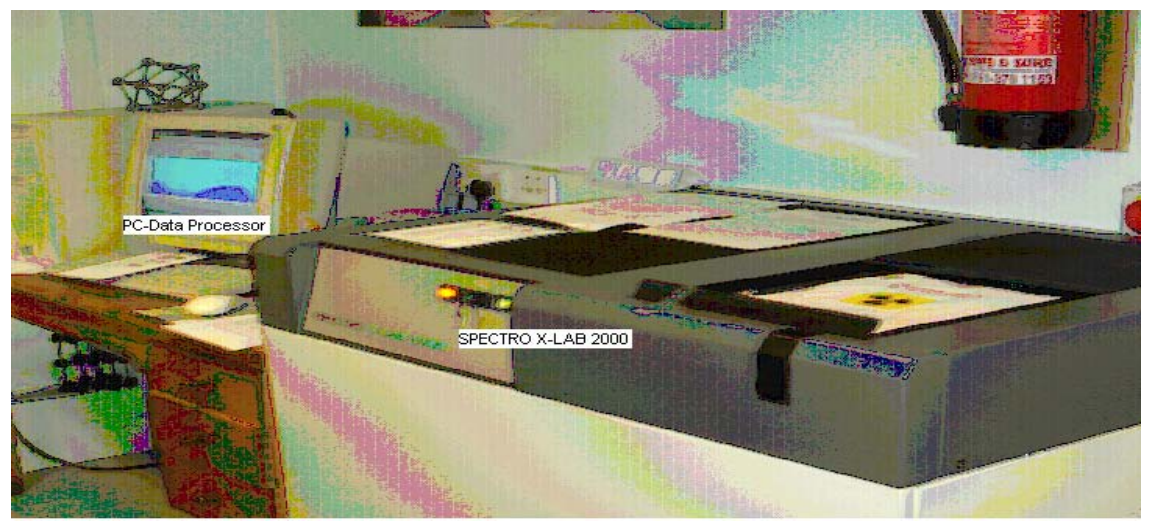

Fig. 2: A photograph of SPECTRA X-LAB 2000 and PC-Data processor

Table 1: Showing resistivity values and layer thicknesses of sounding stations

\begin{tabular}{|c|c|c|c|c|c|c|c|c|}
\hline \multirow[b]{2}{*}{ Station No. } & \multicolumn{4}{|c|}{ Resistivity of layers $(\Omega m)$} & \multicolumn{4}{|c|}{ Thickness of lay ers (m) } \\
\hline & 1 & 2 & 3 & 4 & 1 & 2 & 3 & 4 \\
\hline 1 & 170.00 & 1280.00 & 80.00 & 200.00 & 15.00 & 45.00 & 104.50 & 35.20 \\
\hline 2 & 154.00 & 1300.00 & 78.00 & 190.00 & 18.00 & 31.00 & 125.00 & 25.00 \\
\hline 3 & 160.00 & 1400.00 & 78.00 & - & 18.50 & 51.00 & 128.50 & -4.00 \\
\hline 4 & 220.00 & 1250.00 & 75.00 & - & 16.50 & 58.50 & 124.30 & - \\
\hline 5 & 210.00 & 1180.00 & 77.00 & - & 18.20 & 50.20 & 131.50 & - \\
\hline 6 & 200.00 & 1350.00 & 76.00 & - & 19.30 & 67.50 & 112.00 & - \\
\hline 7 & 190.00 & 1345.00 & 75.00 & - & 12.50 & 86.40 & 100.30 & - \\
\hline 8 & 250.00 & 1500.00 & 78.00 & - & 16.50 & 46.50 & 136.00 & - \\
\hline 9 & 220.00 & 1400.00 & 60.00 & - & 17.50 & 43.50 & 138.20 & - \\
\hline 10 & 200.00 & 1400.00 & 62.00 & - & 15.30 & 50.20 & 134.50 & - \\
\hline 11 & 210.00 & 1420.00 & 67.00 & - & 21.00 & 57.50 & 120.80 & - \\
\hline 12 & 190.00 & 1230.00 & 55.00 & - & 22.30 & 60.70 & 116.50 & - \\
\hline
\end{tabular}




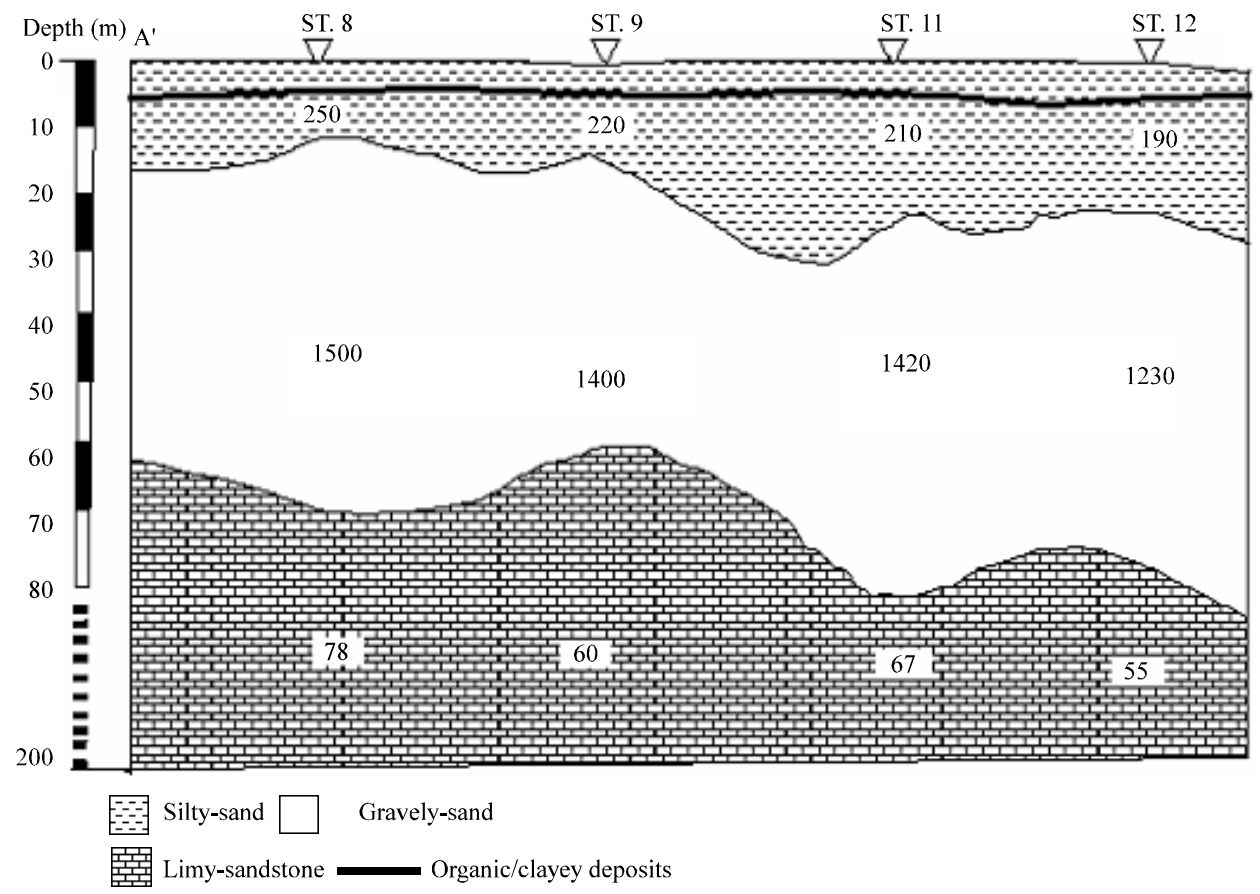

Fig. 3: Resistivity cross-section for profile A'

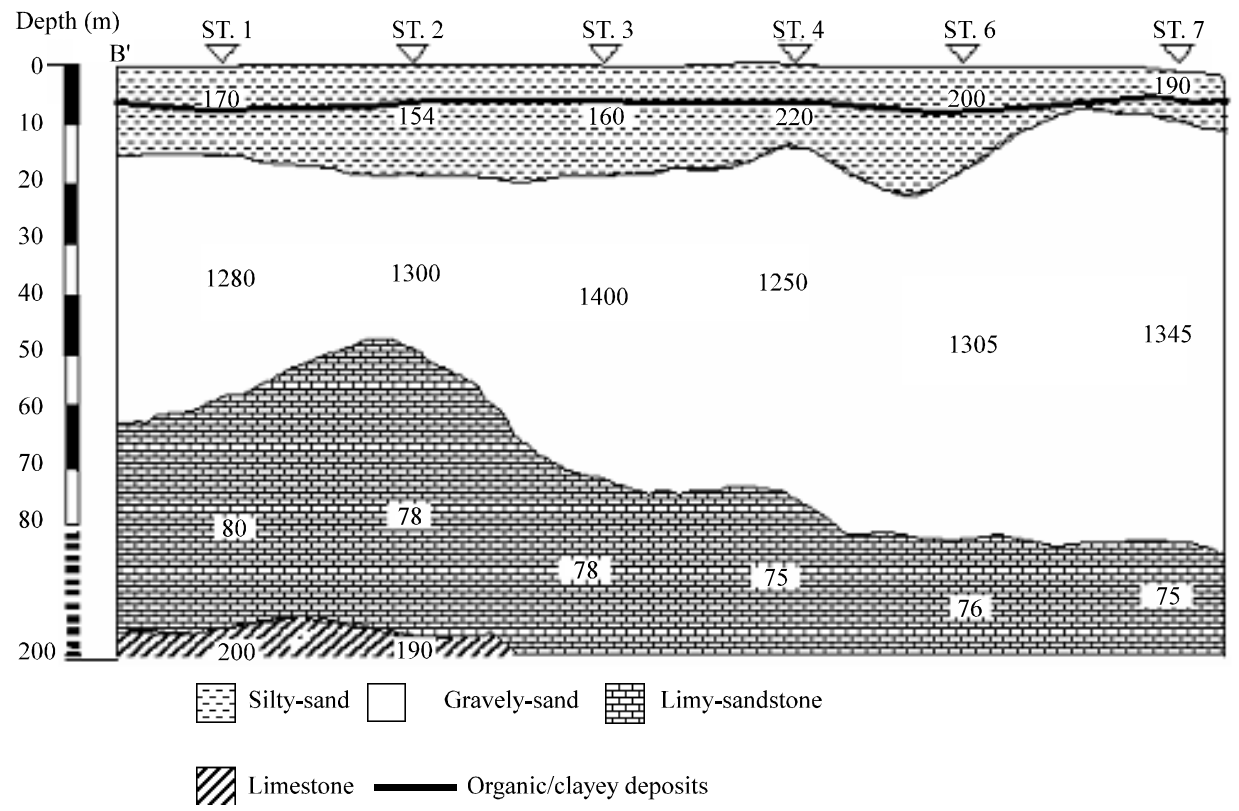

Fig. 4: Resistivity cross-section for profile B'B

values at different sounding points and the thicknesses of the layers as worked out by the current electrode space geometry and the graphical presentation of the resistivities and thicknesses at the sounding stations of the study area are shown in Fig. 3 and 4.
These results from the interpretation revealed that the study area is of three distinct geoelectric/ hydrogeologic layers from the ground surface to the maximum depth (about $200 \mathrm{~m}$ ) that was probed vertically. These layers were distinguished based on their unique formation materials and the resistivity values across 
laterally. From Fig. 3 and 4, the second layer was considered the aquiferous zone because of the high resistivity values between $1230-1500 \Omega m$ meaning that the water therein was the desired fresh water which is less conductive because conductivity of water is dependent on the presence of impurities, salts and pollutants in such water.

Table 2 shown the soil guideline or target values showing the acceptable concentration range of the pollutants of interest. Concentration level of the pollutants beyond these target values is unacceptable. These soil guideline/target values vary depending on the land-use purpose.

The area of study is an Urban development area which was not used for farming as such the problem of bioaccumulation of these pollutants by plants or animals was not seriously put into consideration, thus these target values.

The chemical analysis results of the soil samples at various depths for the three pollutants are also shown in Table 3-5 for $\mathrm{Pb}, \mathrm{Cu}$ and $\mathrm{Ni}$, respectively. While the

Table 2: Soil guideline/target values (Fuentes et al., 2004)

\begin{tabular}{lc}
\hline Pollutants & Soil guideline/Target values $\left(\mu \mathrm{g} \mathrm{g}^{-1}\right)$ \\
\hline Lead $(\mathrm{Pb})$ & $85-450$ \\
Copper $(\mathrm{Cu})$ & $30-40$ \\
Nickel $(\mathrm{Ni})$ & $30-75$ \\
\hline
\end{tabular}

graphical presentations of the chemical analysis results of the elements are shown in Fig. 5-7 for $\mathrm{Pb}, \mathrm{Cu}$ and $\mathrm{Ni}$, respectively.

These results clearly revealed that the concentration of the pollutants $(\mathrm{Pb}, \mathrm{Cu}$ and $\mathrm{Ni})$ at the ground surface of almost all the sampling locations is so high and far beyond the permissible level and therefore calls for urgent intervention by private and government agencies for proper monitoring and control of these anthropogenic activities.

At $5 \mathrm{~m}$ depth, the analytical results also show significant concentration of the pollutants averagely beyond the permissible level; perhaps due to reasonable amount of the pollutants been leached down from the surface during percolation of rain water down the earth interior.

Nevertheless, from 10-25 $\mathrm{m}$ down, the concentrations of the pollutants was sharply low far below the target limits and well within the permissible limits of concentration as clearly shown by Fig. 5-7 which perhaps is due to the presence of Organic and clayey deposits observed between 6-8 $\mathrm{m}$ depth across the area as shown by Fig. 3 and 4 that may have provided mechanical filtration of colloidal pollutants such as pathogens and chemicals owing to their fine-grain sizes that adsorb these pollutants and sorption of charge

Table 3: Total concentration of lead $(\mathrm{Pb})$

\begin{tabular}{|c|c|c|c|c|c|c|}
\hline \multirow{2}{*}{$\begin{array}{l}\text { Sample locations/ } \\
\text { Sampling depths }\end{array}$} & \multicolumn{6}{|c|}{ Concentration values $\left(\mu \mathrm{g} \mathrm{g}^{-1}\right)$} \\
\hline & $\mathrm{A}=0 \mathrm{~m}$ & $\mathrm{~B}=5 \mathrm{~m}$ & $\mathrm{C}=10 \mathrm{~m}$ & $\mathrm{D}=15 \mathrm{~m}$ & $\mathrm{E}=20 \mathrm{~m}$ & $\mathrm{~F}=25 \mathrm{~m}$ \\
\hline SP. 1 & $854.3 \pm 3.6$ & $458.7 \pm 2.1$ & $171.5 \pm 1.7$ & $80.3 \pm 0.7$ & $38.5 \pm 0.5$ & $22.8 \pm 1.1$ \\
\hline SP. 2 & $840.0 \pm 3.6$ & $502.4 \pm 2.2$ & $145.3 \pm 1.7$ & $66.5 \pm 0.9$ & $28.2 \pm 0.5$ & $21.7 \pm 0.8$ \\
\hline SP. 3 & $525.2 \pm 2.9$ & $419.7 \pm 1.8$ & $98.6 \pm 1.1$ & $45.2 \pm 1.1$ & $22.5 \pm 0.6$ & $14.3 \pm 0.4$ \\
\hline SP. 4 & $533.4 \pm 3.2$ & $394.8 \pm 2.0$ & $88.2 \pm 0.7$ & $42.1 \pm 0.5$ & $19.6 \pm 0.4$ & $11.5 \pm 0.3$ \\
\hline SP. 5 & $465.0 \pm 2.8$ & $306.5 \pm 1.7$ & $102.5 \pm 1.0$ & $48.3 \pm 0.8$ & $21.7 \pm 0.6$ & $18.4 \pm 0.5$ \\
\hline SP. 6 & $388.6 \pm 4.1$ & $249.2 \pm 1.8$ & $121.3 \pm 0.8$ & $51.4 \pm 1.2$ & $20.9 \pm 0.4$ & $20.7 \pm 0.4$ \\
\hline SP. 7 & $275.0 \pm 2.7$ & $201.3 \pm 1.4$ & $82.6 \pm 0.7$ & $40.4 \pm 0.7$ & $18.3 \pm 0.9$ & $12.5 \pm 0.4$ \\
\hline SP. 8 & $411.5 \pm 3.0$ & $277.6 \pm 16$ & $91.5 \pm 0.8$ & $43.1 \pm 1.0$ & $16.4 \pm 0.5$ & $\mathrm{ND}$ \\
\hline SP. 9 & $165.7 \pm 1.6$ & $111.4 \pm 0.7$ & $56.9 \pm 0.4$ & $30.2 \pm 0.5$ & $13.8 \pm 0.7$ & ND \\
\hline SP. 10 & $228.5 \pm 2.3$ & $134.5 \pm 0.9$ & $71.4 \pm 0.6$ & $34.6 \pm 0.7$ & $11.3 \pm 0.3$ & ND \\
\hline
\end{tabular}

Table 4: Total concentration of Copper (Cu)

\begin{tabular}{|c|c|c|c|c|c|c|}
\hline \multirow[b]{2}{*}{$\begin{array}{l}\text { Sample locations/ } \\
\text { Sampling depths }\end{array}$} & \multicolumn{6}{|c|}{ Concentration values $\left(\mu \mathrm{g} \mathrm{g}^{-1}\right)$} \\
\hline & $\mathrm{A}=0 \mathrm{~m}$ & $\mathrm{~B}=5 \mathrm{~m}$ & $\mathrm{C}=10 \mathrm{~m}$ & $\mathrm{D}=15 \mathrm{~m}$ & $\mathrm{E}=20 \mathrm{~m}$ & $\mathrm{~F}=25 \mathrm{~m}$ \\
\hline SP. 1 & $153.5 \pm 2.2$ & $113.6 \pm 0.9$ & $43.8 \pm 0.6$ & $19.7 \pm 0.5$ & $17.2 \pm 0.6$ & $17.0 \pm 0.6$ \\
\hline SP. 2 & $101.9 \pm 1.7$ & $73.1 \pm 0.7$ & $28.5 \pm 0.7$ & $14.6 \pm 0.6$ & $14.0 \pm 0.6$ & $12.4 \pm 0.5$ \\
\hline SP. 3 & $81.5 \pm 1.5$ & $52.4 \pm 0.7$ & $23.5 \pm 0.7$ & $13.2 \pm 0.5$ & $13.2 \pm 0.5$ & $12.5 \pm 0.5$ \\
\hline SP. 4 & $97.8 \pm 1.6$ & $50.8 \pm 0.8$ & $21.2 \pm 0.3$ & $13.0 \pm 0.5$ & $10.8 \pm 0.5$ & $8.6 \pm 0.4$ \\
\hline SP. 5 & $80.5 \pm 1.3$ & $38.5 \pm 0.5$ & $14.8 \pm 0.4$ & $10.4 \pm 0.7$ & $7.9 \pm 0.5$ & $7.9 \pm 0.5$ \\
\hline SP. 6 & $73.2 \pm 1.4$ & $41.7 \pm 1.0$ & $18.6 \pm 0.5$ & $12.8 \pm 0.6$ & $7.6 \pm 0.4$ & $7.6 \pm 0.4$ \\
\hline SP. 7 & $122.6 \pm 1.9$ & $59.2 \pm 1.2$ & $22.9 \pm 1.0$ & $13.0 \pm 0.5$ & $10.7 \pm 0.5$ & $8.2 \pm 0.5$ \\
\hline SP. 8 & $104.7 \pm 0.8$ & $51.3 \pm 0.6$ & $20.1 \pm 0.8$ & $13.4 \pm 0.5$ & $8.0 \pm 0.4$ & $5.8 \pm 0.3$ \\
\hline SP. 9 & $56.3 \pm 0.6$ & $30.3 \pm 0.5$ & $12.4 \pm 0.3$ & $12.2 \pm 0.3$ & $12.0 \pm 0.3$ & $9.4 \pm 0.3$ \\
\hline SP. 10 & $62.7 \pm 0.5$ & $37.9 \pm 0.4$ & $12.0 \pm 0.3$ & $10.2 \pm 0.3$ & $7.5 \pm 0.3$ & $7.5 \pm 0.3$ \\
\hline
\end{tabular}


Res. J. Applied Sci., 5 (3): 204-211, 2010

Table 5: Total concentration of Nickel (Ni)

\begin{tabular}{|c|c|c|c|c|c|c|}
\hline \multirow{2}{*}{$\begin{array}{l}\text { Sample locations/ } \\
\text { Sampling depths }\end{array}$} & \multicolumn{6}{|c|}{ Concentration values $\left(\mu \mathrm{g} \mathrm{g}^{-1}\right)$} \\
\hline & $\mathrm{A}=0 \mathrm{~m}$ & $\mathrm{~B}=5 \mathrm{~m}$ & $\mathrm{C}=10 \mathrm{~m}$ & $\mathrm{D}=15 \mathrm{~m}$ & $\mathrm{E}=20 \mathrm{~m}$ & $\mathrm{~F}=25 \mathrm{~m}$ \\
\hline SP. 1 & $201.6 \pm 2.3$ & $113.5 \pm 2.1$ & $45.7 \pm 1.1$ & $23.5 \pm 0.6$ & $16.7 \pm 0.5$ & $9.8 \pm 0.5$ \\
\hline SP. 2 & $172.8 \pm 3.0$ & $101.8 \pm 1.5$ & $38.5 \pm 0.7$ & $11.3 \pm 0.3$ & $11.3 \pm 0.3$ & $10.0 \pm 0.3$ \\
\hline SP. 3 & $139.2 \pm 2.2$ & $97.1 \pm 0.9$ & $42.6 \pm 1.2$ & $24.8 \pm 0.8$ & $14.5 \pm 0.5$ & $8.5 \pm 0.3$ \\
\hline SP. 4 & $89.9 \pm 1.6$ & $80.6 \pm 1.3$ & $31.5 \pm 0.8$ & $12.9 \pm 0.6$ & $12.9 \pm 0.6$ & $12.0 \pm 0.6$ \\
\hline SP. 5 & $60.7 \pm 1.2$ & $60.7 \pm 1.2$ & $29.4 \pm 0.4$ & $14.4 \pm 0.0$ & $8.3 \pm 0.6$ & ND \\
\hline SP. 6 & $95.0 \pm 2.2$ & $65.6 \pm 1.6$ & $27.9 \pm 0.5$ & $8.3 \pm 0.2$ & $\mathrm{ND}$ & $\mathrm{ND}$ \\
\hline SP. 7 & $126.7 \pm 1.6$ & $103.5 \pm 1.5$ & $41.4 \pm 0.9$ & $15.9 \pm 0.7$ & $6.8 \pm 0.3$ & $\mathrm{ND}$ \\
\hline SP. 8 & $87.7 \pm 1.5$ & $70.1 \pm 1.0$ & $30.8 \pm 0.5$ & $12.4 \pm 0.4$ & $8.2 \pm 0.4$ & $5.4 \pm 0.2$ \\
\hline SP. 9 & $72.3 \pm 1.3$ & $53.8 \pm 0.7$ & $22.6 \pm 0.3$ & $7.3 \pm 0.0$ & $\mathrm{ND}$ & ND \\
\hline SP. 10 & $107.3 \pm 1.5$ & $79.0 \pm 1.4$ & $29.3 \pm 0.5$ & $12.7 \pm 0.3$ & $6.5 \pm 0.3$ & $\mathrm{ND}$ \\
\hline
\end{tabular}

$\mathrm{ND}=$ Not Detected

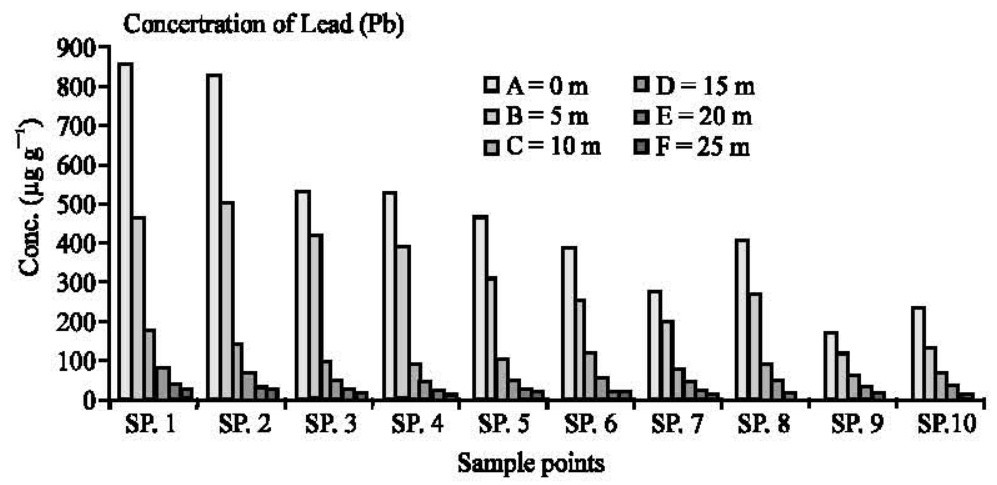

Fig. 5: Concentration of Lead $(\mathrm{Pb})$ from the sampling points at various depths

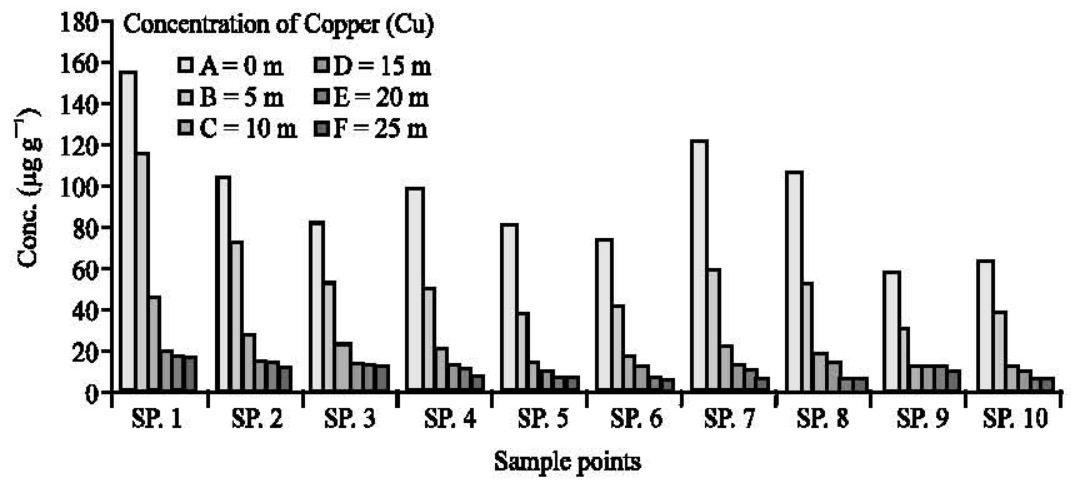

Fig. 6: Concentration of Copper $(\mathrm{Cu})$ from the sampling points at various depths

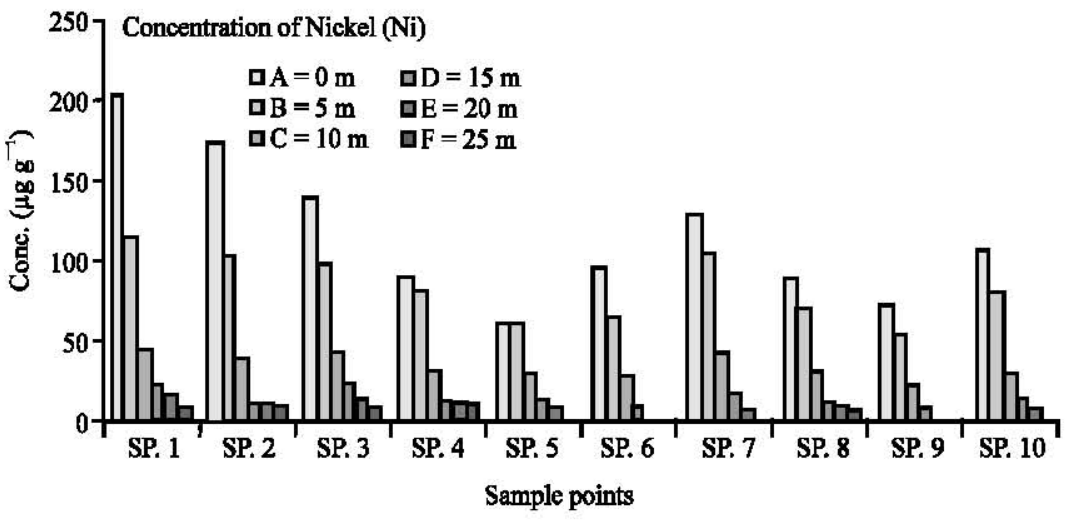

Fig. 7: Concentration of Nickel (Ni) from the sampling points at various depths 
pollutant species due to their charged surfaces and large surface areas; this favours the washing away of pollutant deposited on the surface by runoff thereby minimize or prevent the leaching of even the water soluble components of the pollutant down to the groundwater during percolation of rain water or snow that precipitate on the ground surface.

\section{CONCLUSION}

This research puts together two distinct studies: aquifer delineation and leaching of surface pollutants to be able to correctly establish the vulnerability of the groundwater resource. The results of this research have revealed the amount and concentration of pollutants deposited unto the soil as a result of uncontrolled and unmonitored anthropogenic activities in the area. The concentration of these pollutants $(\mathrm{Pb}, \mathrm{Cu}$ and $\mathrm{Ni})$ at the ground surface is alarming as shown by Fig. 5-7 this calls for intervention, though there was an observed decreasing trend of their concentration with depth especially from 10-25 $\mathrm{m}$ depth.

This research also clearly delineated the aquiferous zone which laterally spread across the study area. This aquifer varies in thickness from station to station but within the thickness range of 50-60 m which indicates a very good aquifer. Figure 3 and 4 show the lithostratigraphic distribution within the study area having three hydrogeologic layers with a thin band of organic and clayey deposits within the top layer embedded at around 6-8 $\mathrm{m}$ depth. This thin band of organic and clayey deposits was not detected by the geoelectric sounding method, perhaps due to suppression. This layer was mapped during drilling to obtain the soil samples. To precisely define this thin band or layer, a crosshole-seismic method may be required.

The sharp reduction of the concentration of the pollutants from 10-25 $\mathrm{m}$ was perhaps due to the presence of this thin band or layer of organic and clayey deposits within the top hydrogeologic layer embedded at around 6-8 $\mathrm{m}$ depth which may have provided mechanical filtration of colloidal pollutants such as pathogens and chemicals owing to their fine-grain sizes and sorption of charge pollutant species due to their charged surfaces and large surface areas (Kilner et al., 2005).

The aquifer characteristics makes the aquifers of the area reliable water resources that can supply reasonable millions of $\mathrm{m}^{3}$ volume of water to satisfy the water needs of the people and industries of the area through both public and private abstractions. While the minimal leaching of surface pollutants renders the groundwater resource less vulnerable to surface pollutants despite the continuous human and industrial activities in the area.

Finally, to safeguard and preserve this all important resource, there should be regular determination and evaluation of the mobility of these surface pollutants toward the groundwater and establishment of the safety status of the groundwater resource.

\section{ACKNOWLEDGEMENTS}

The researchers are very grateful to the staff of the Rivers State water board of the ministry of water resources for providing useful information to the actualization of this research. Researchers are also grateful to the Institute of Pollution Studies, Rivers State University of Science and Technology, Port Harcourt for their technical assistance. Success computers are also well appreciated for their assistance in data analysis.

\section{REFERENCES}

Aloway, B.J. and D.C. Ayres, 1997. Chemical Principles of Environmental Pollution. 2ndEdn., Blackie Academic and Professional, UK., pp: 190-217.

Amadi, U.M.P. and P.A. Amadi, 1990. Saltwater migration in the coastal aquifer of Southern Nigeria. Nig. J. Min. Geol., 26: 35-44.

Breusse, J.J., 1963. Modern geophysical methods for sub-surface water exploration Geophys, 28: 633-654.

Etu-Efeotor, J.O., E.H. Alabo and A. Michaisk, 1989. Geophysical investigation for groundwater in parts of Eastern Niger Delta. Nig. J. Min. Geol., 25: 51-54.

Frohlich, R.K., 1974. Combined geoelectric and drilled hole investigation for detecting aquifer in North-West Missouri. Geophysics, 39: 340-352.

Fuentes, A., M. Llorens, J. Saez, M.I. Aguilar, J.F. Ortuno and V.F. Meseguer, 2004. Phytotoxicity and heavy metals speciation of stabilized sewage sludge. J. Hazard. Mater. A, 108: 161-169.

Kebbekus, B.B. and S. Mitra, 1997. Environmental Chemical Analysis. Blackie Academic and Professional, Glasgow, UK.

Kilner, M., L.J. West and T. Murray, 2005. Characterization of glacial sediments using geophysical methods for groundwater source protection. J. Applied Geophys., 57: 293-305.

Koefoed, O. and F.J.H. Dirks, 1979. Determination of resistivity sounding filters by the wiener hopf least square method. Geophys. Prospect, 27: 245-250.

Mbonu, P.D.C., J.O. Ebeniro, C.O. Ofoegbu and A.S. Ekine, 1991. Geoelectric sounding for the determination of aquifer characteristics in parts of the Umuahia area of Nigeria. Geophysics, 56: 284-291. 
Oteri, A.U., 1990. Delineation of seawater intrusion in a coastal beach ridge of forcadoes. Nig. J. Min. Geol., 26: $225-229$.

Plummer, C.C. and D. McGeary, 1993. Physical Geology. 6th Edn., Wm. C., Brown Publishers, England.

Short, K.C. and A.J. Stauble, 1967. Outline geology of Niger delta. AAPG. Bull., 51: 761-779.

Stead-Dexter, K. and N.I. Ward, 2004. Mobility of heavy metals within freshwater sediments affected by motorway stormwater. Sci. Total Environ., 334-335: 271-277.
Todd, D.K., 1959. Groundwater Hydrology. John Wiley and Sons, Inc., New York, pp: 44-84.

Urish, D.W. and R.K. Frohlich, 1990. Surface electrical resistivity in coastal groundwater exploration. Geoexploration, 26: 267-289.

Zohdy, A.A.R. and D.B. Jackson, 1969. Application of deep electric sounding for groundwater exploration in Hawaii. Geophys, 34: 584-600.

Zohdy, A.A.R., 1969. The use of schlumberger and equatorial sounding in groundwater investigation near El-Paso. Geophys, 34: 713-728. 